\title{
Characterization of the Variability of Nucleoli in the Cells of Panax ginseng Meyer In Vivo and In Vitro
}

\author{
Yuliya A. Khrolenko ${ }^{*}$, Olga L. Burundukova ${ }^{1}$, Lyudmila S. Lauve ${ }^{1}$, Tamara I. Muzarok ${ }^{1}$, \\ Vyacheslav V. Makhan'kov², and Yuri N. Zhuravlev' \\ ${ }^{1}$ Institute of Biology and Soil Science, Far Eastern Branch of Russian Academy of Science, Vladivostok 690-022, Russia \\ ${ }^{2}$ Pacific Institute of Bioorganic Chemistry, Far Eastern Branch of Russian Academy of Science, Vladivostok 690-022, Russia
}

Results of karyological study of intact plants and some callus lines of Panax ginseng are presented. In the native plants of $P$. ginseng the nucleus with 1 nucleolus (90\%) dominate, and nucleus with 2 nucleoli is rare. One nucleolar nucleus also dominate in interphase nuclei of cells of cultivated P. ginseng (from 2006), but we also found nucleus with 2 to 3 nucleoli in the same cell lines. Interphase nuclei of $P$. ginseng in long cultivated lines (from 1988) contain 1 to 9 nucleoli, with a predominance of nuclei containing from 3 to 4 nucleoli. It was shown that long-time cells (cultivated since 1988) had cytogenetic changes such as increase level of polyploid and aneuploid cells, increase of nucleoli number into interphase nucleus and decrease of nuclei/nucleoli ratio. These long-time cultivated cells had very low ginsenoside content.

Keywords: Panax ginseng, In vivo, In vitro, Nucleoli, Ginsenoside content

\section{INTRODUCTION}

Panax ginseng Meyer (Araliaceae) is a perennial officinal herb. It is a rare relict species and it was listed in the Red Books of USSR and Russian Federation [1,2]. In 2000 by decision of Conference of the Parties of the Convention on International Trade of Endangered Species of Wild Fauna and Flora (CITES) P. ginseng (wild plant roots) has been included in annex II the CITES. Introducing of $P$. ginseng into culture in vitro and creating collection of its cell cultures is one of the important elements in the strategy which is aimed to retain the gene pool of ginseng. Cell cultures of $P$. ginseng are used for examining of secondary metabolites synthesis and obtaining the alternative source of bioactive substances [35]. When we introduced plant cells into the cell culture the latter often lost their genetic stability, and formation of high level polyploidy and aneuploidy could be seen

(cc) This is an Open Access article distributed under the terms of the Creative Commons Attribution Non-Commercial License (http://creativecommons.org/licenses/by-nc/3.0/) which permits unrestricted non-commercial use, distribution, and reproduction in any medium, provided the original work is properly cited.
[6]. In literature one can find data about wild $P$. ginseng chromosome numbers that is determined as $2 n=24,44$, 48, and karyotype is shortly described as well [7-9]. Data of chromosome cytologic analysis could be used as the evidence to genetic variability of plant cells cultivated in vitro; but it is difficult to describe karyotype in detail, because chromosome size of $P$. ginseng is very small (2-5 $\mu \mathrm{m}$ and less). Reliability of data obtained by measuring of length of such chromosomes is quite questionable, because resolution of light microscope is just $0.5 \mu \mathrm{m}$. But there are some techniques, which allow to determine the influence of physical and chemical factors on living organisms - by identifying capacity of cell's genome (without determining structural rearrangements of karyotype) [10]. Thus, nucleoli characteristics are successfully used as biotests of high sensitivity. Determination of

Received 15 Oct. 2010, Revised 16 Jun. 2011, Accepted 20 Jun. 2011

*Corresponding author

E-mail: khrolenko@biosoil.ru

Tel: +8-4232-310- 410, Fax: +8-4232-310-193 
nucleoli number and their size allows to assess gene activity of ribosomal RNA on cytological level $[11,12]$. In Gorpenchenko's dissertation [13], it has been noted that nuclei with two or more nucleoli can be found in callus cells of $P$. ginseng. In our research work the investigation of nucleolus-forming locus activity in native plants of $P$. ginseng and its cell cultures with different passaging time has been performed using karyometric technique.

\section{MATERIALS AND METHODS}

Seedlings were obtained from seeds of cultivated ginseng in the ginseng farm from the Institute of Biology and Soil Science. Callus line 1c was obtained from a leafstalk of a two-month-old plant from a cultivated P. ginseng population in 1988 [4]. Callus line no. 8 was obtained from a leafstalk of plant from a cultivated $P$. ginseng population in 2006. Samples were taken after cell and tissue cultures were grown for $18 \mathrm{~d}$. The materials were prepared and analyzed according to generally accepted techniques for fruit plants [14] with some modifications. Cell, tissue cultures (volume $0.5-1 \mathrm{~mL}$ ) and actively growing root tips were pretreated in $0.2 \%$ colchicine solution for 2 to $3 \mathrm{~h}$ at room temperature (about $22^{\circ} \mathrm{C}$ ), fixed in 3:1 ethanol:acetic acid mixture and stained with acetohematoxylin. The slides were prepared using the squash technique. The somatic chromosome number was studied in at least 60 well-prepared metaphase plates. A $50 \%$ solution of silver nitrate was used to stain nucleoli [15].

\section{Ginsenoside content}

Analytical HPLC of the ginseng samples were performed on a LaChrom (Merck Hitachi, Tokyo, Japan) system (pump L-7100, UV detector L-7400, column oven L-7300, and integrator D-7500). Separations were carried out using Agilent Technologies column Hypersil ODS $5 \mu \mathrm{m}(25 \mathrm{~cm} \times 4.0 \mathrm{~mm})$ with a guard column Hypersil ODS. The binary gradient employed water (A) and acetonitrile (B) according to the following profile: $0-17$ $\min , 82 \%-78 \%$ A, $18 \%-22 \%$ B; $17-20$ min, $78 \%-76 \%$ A, $22 \%-24 \%$ B; $20-35$ min, $76 \%-65 \%$ A, 24\%-35\% B; 3540 min, $65 \%-60 \%$ A, 35\%-40\% B; $40-50$ min, $65 \%-50 \%$ A, 35\%-50\% B; 50-55 min, 50\%-30\% A, 50-70\% B; 55$60 \mathrm{~min}, 30 \% \mathrm{~A}, 70 \% \mathrm{~B}$. The flow-rate was $1.0 \mathrm{~mL} / \mathrm{min}$.

\section{RESULTS AND DISCUSSION}

The inherent property of $P$. ginseng is chromosomal variability both for callus culture and wild plants $[3,4]$. For the latter diploid $(2 n=24)$ and tetraploid $(2 n=48)$ cytotypes are known [9]. Dividing cells of investigated plants had from 6 to 60 chromosomes, callus cells - from 6 to 150 chromosomes, but cells with $2 n=48$ chromosomes formed modal class (Table 1 and Fig. 1A).

Studying of nucleoli in interphase nuclei of $P$. ginseng has shown that number of nucleoli in cells of intact plants varies from 1 to 2 , in cells of callus no. 8 from 1 to 3 , and in cells of old callus from 1 to 9 (Figs. 1B and Fig. 2).

In the first case, average number of nucleoli per cell is $1.14 \pm 0.03$, in the second $-1.19 \pm 0.03$, and in the third $4.3 \pm 0.17$ respectively. The frequency of nucleoli's occur-

Table 1. Frequency of cells varying in chromosome number in Panax ginseng: intact plants, line 1c, and line no. 8

\begin{tabular}{lccc}
\hline \multirow{2}{*}{. ginseng } & \multicolumn{3}{c}{ Cell mixoploidy } \\
\cline { 2 - 4 } & Minimum & Maximum & $>50 \%$ modal \\
\hline Plant native & $2 \mathrm{n}=6$ & $2 \mathrm{n}=60$ & $24-48$ \\
Callus line no. 8 & $2 \mathrm{n}=6$ & $2 \mathrm{n}=90$ & $24-60$ \\
Callus line 1c & $2 \mathrm{n}=6$ & $2 \mathrm{n}=150$ & $36-80$ \\
\hline
\end{tabular}

A

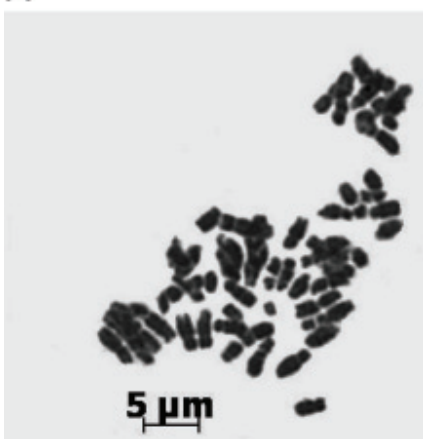

B

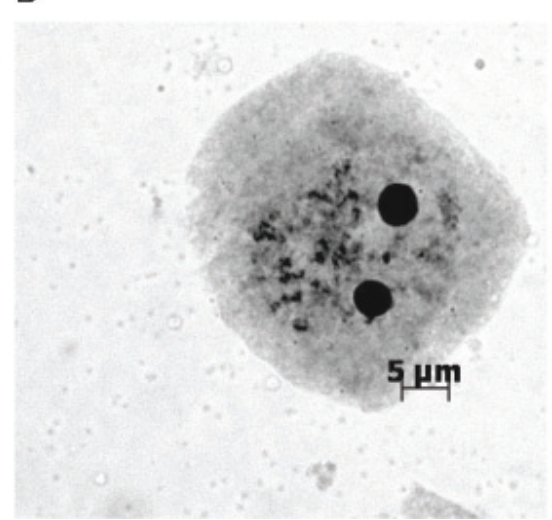

Fig. 1. The cells of intact plants of Panax ginseng. (A) Chromosome complement, (B) nucleoli. 
A

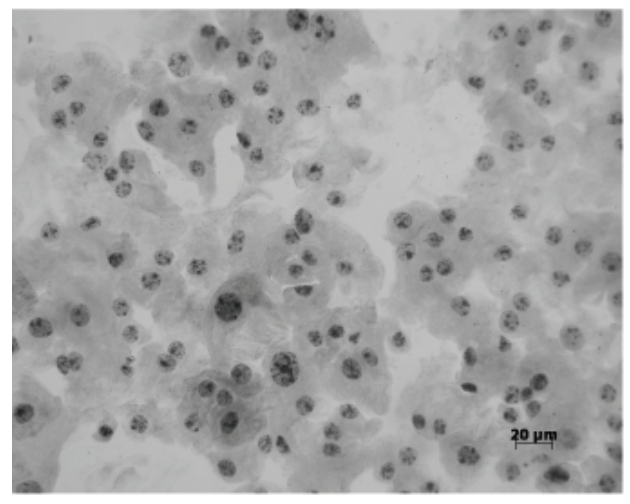

B

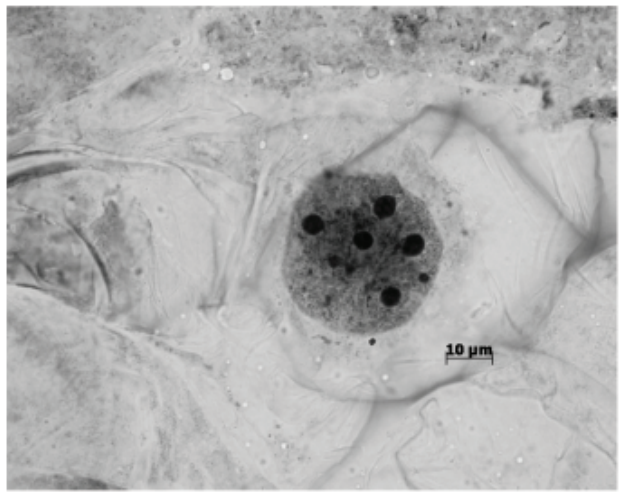

Fig. 2. Cells of the callus line 1c. (A) View of cultivated cells, (B) interphase nuclei with nucleoli.

A

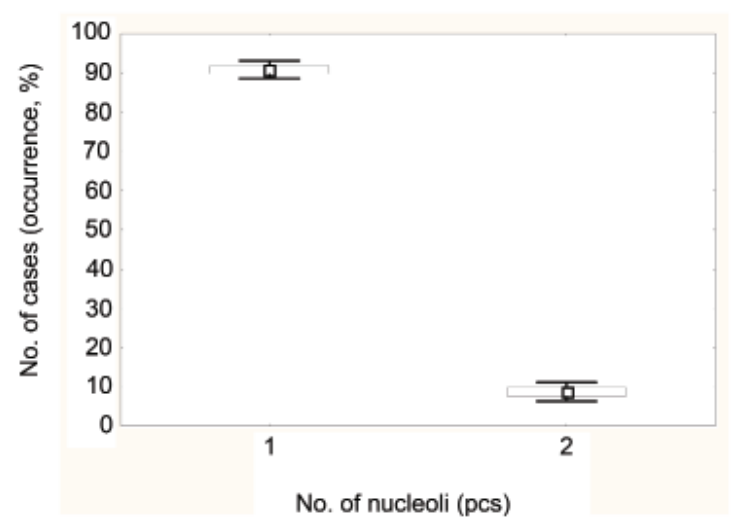

C

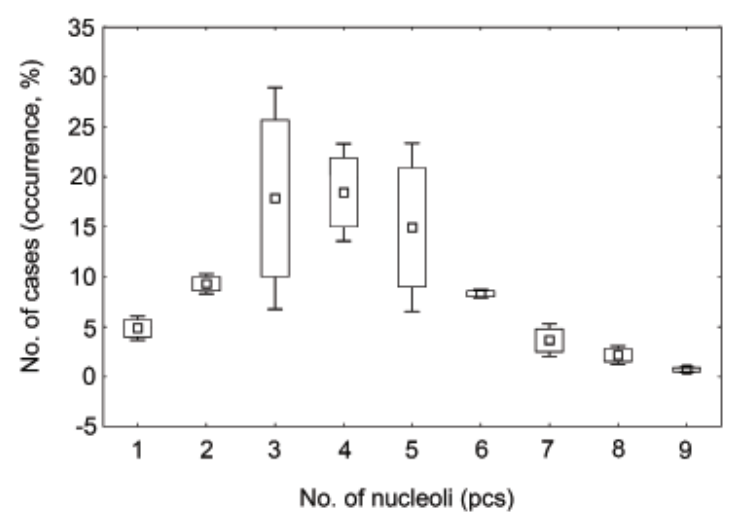

B

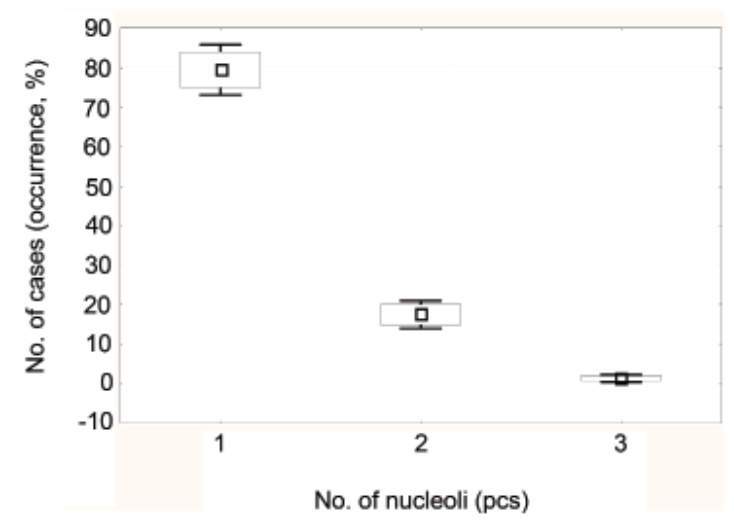

Fig. 3. The number of nucleoli in interphase nuclei of Panax ginseng. (A) In the cells of native plants, (B) in the cells of callus lines no. 8, (C) in the cells of callus lines 1c. The square symbols in each box indicate the mean value, the bottom and top parts of the box the standard error and the bottom and top parts of the bars the standard deviation. pcs, pieces.

rence in interphase nuclei of $P$. ginseng is shown on Fig. 3.

In native plants interphase nuclei with 1 nucleolus occur more frequently $(90 \%)$, and nuclei with 2 nucleoli - much less frequently (10\%). In the cells of cultivated lines (from 2006) there are $80 \%$ (of total amount of nuclei analyzed) of interphase nuclei with 1 nucleolus, and much less nuclei with 2 to 3 nucleoli (18\% and $2 \%$ respectively). Cell cultures passaged for a long time (since 1988) have more interphase nuclei with 3,4 , and 5 nucleoli $(60 \%$ of all cells). 
Table 2. Parameters of the nucleus and nucleolus in Panax ginseng: intact plants, callus lines

\begin{tabular}{cccc}
\hline $\begin{array}{c}P . \text { ginseng } \\
\text { (no. of studied nucleus) }\end{array}$ & Nucleus area $\left(\mu \mathrm{m}^{2}\right)$ & $\begin{array}{c}\text { Area nucleoli }\left(\mu \mathrm{m}^{2}\right) \\
\text { (sum of the areas of all nucleolus) }\end{array}$ & Nuclei/nucleoli ratio \\
\hline Intact plants (663) & $882.77 \pm 85.04$ & $68.01 \pm 10.49$ & $12.98 \pm 0.54$ \\
Callus line 1c (252) & $961.63 \pm 60.63$ & $100.27 \pm 3.76$ & $9.59 \pm 1.01$ \\
\hline
\end{tabular}

Nucleoli formation is determined by some chromosome locus activity - so called nucleoli organizers commonly situated in the zone of secondary chromosomal constrictions, where genes controlling synthesis of rRNA and formation of ribosomes (triggers for synthesis of protein) are placed [11]. Number of nucleoli formed in mitosis telophase allows to estimate the number of nucleolar chromosomes. Maximal nucleoli number in interphase nuclei allows to determine the number of nucleoli-forming chromosomes. Interphase nuclei of native $P$. ginseng have from 1 to 2 nucleoli, that allow to suggest the presence of one pair of nucleolar chromosomes. Nuclei of callus cells of $P$. ginseng (2006) have from 1 to 3 nucleoli, and nuclei of old ones - from 1 to 9 nucleoli, so we can suggest activity of 1 to 2 and 4 to 5 pairs of nucleolar chromosomes, respectively.

Nuclei/nucleoli ratio is good parameter, reflecting activity of system of protein synthesis in the cell [16]. This ratio shows differences in the rate of protein biosynthesis, i.e., decreasing of niclei/nucleoli ratio means increasing of nucleolus volume in the nucleus, and that implies intensification of biosynthesis in the cell, and vice versa. Data on value of nuclei/nucleoli ratio are given in Table 2.

On the basis of obtained data we can conclude that synthesis of rRNA and some stages of ribosomes formation and, therefore, protein synthesis is much more intensive in the cells of that lines of $P$. ginseng, which were cultivated for a long time due to increased quantity of nucleoli organizers. Probably, extra-activation of nucleoli-forming zones (that are inactive in native plants) occurs during long passaging. Greater amount of nucleoli in interphase nuclei seems to be connected with greater ploidy level (thus, in culture 1c part of mixoploid cells $2 n=91,100,150$ is very high).

It is known from literature, that some species are able to maintain stability of chromosomes morphology if callus is cultivated for a long time [17]. And it was also shown for callus cells of $P$. ginseng, that they have the same modal class of chromosome number as in intact plants, but callus lines had high aneuploidy, and at the same time low DNA variability, determined by RAPD [4].

Present data clearly shows that unlike native plants of $P$. ginseng (which karyotype has one pair of chromosomes with secondary constrictions), callus lines have up to 4 to 5 pairs of such chromosomes. Kozyrenko et al. [4] have shown that culture $1 \mathrm{c}$ is characterized by mixoploid cells with maximal chromosome number $2 n=72$ (5\% of all cells analysed), and in 8 years research we found mixoploids $2 \mathrm{n}=91,100,150$ in callus cells of culture $1 \mathrm{c}$ and their part in culture is $25 \%$, this factor probably influences the number of nucleoli in interphase nuclei.

Total number of nucleoli per nucleus is increasing when polyploidy (and also aneuploidy) takes place, but increasing of chromosome complements does not lead automatically to duplication of total nucleoli number $[11,12,18]$. Examples of polyploidy in cell cultures are given in articles of Kunakh et al. [5] for $P$. ginseng and of Dorofeev et al. [19] for Atragene speciosa Weinm. Authors suggest that change of flavonoid and saponin levels (type of compounds which includes glycosides) is the result of genetic variability of culture in vitro, because of changes in ploidy $[5,19]$.

It should be noted that in the case of $P$. ginseng polyploidy led to growth enhancement but was not accompanied by increased accumulation of triterpene glycosides, and in the case of A. speciosa on the contrary polyploidy promoted almost double increasing of saponines content. Maximal accumulation of glycosides is inherent to cell cultures of $P$. ginseng, which cytogenetic characteristics are close to that of intact plants [5].

Quantitative analysis of ginsenosides from ginseng cell cultures, induced from leafstalk of seedling and intact leafstalk of seedling were examined (Table 3). Content of ginsenosides from long-term cells cultivated since 2006 was noticeably higher than from long-time cells cultivated since 1988, but it was less ginsenoside content from intact leafstalk of seedling. $\mathrm{Rg} / \mathrm{Rb}$ ratio indicated that contents of protopanaxatriol glycosides were dominated in all patterns.

It was shown that long-time cells (cultivated since 1988) had cytogenetic changes such as increase level of polyploid and aneuploid cells, increase of nucleoli number into interphase nucleus and decrease of nuclei/ nucleoli ratio. These long-time cultivated cells had very low ginsenoside content. Long-term cells cultivated since 2006 had cytogenetic characteristic like intact plant.

Thereby, it is possible that nucleoli test will signal about processes of biosynthesis in cultivated cells of 
Table 3. Content of ginsenosides

\begin{tabular}{lcc}
\hline Panax ginseng & Content of ginsenosides $(\mathrm{mg} / \mathrm{g})$ & $\mathrm{Rg}^{1 /} / \mathrm{Rb}^{2)}$ \\
\hline Leafstalk of seedling & $5-10$ & $2.7-14$ \\
Callus line no. 8 (2006) & $1.35-1.66$ & $1.05-8.9$ \\
Callus line 1c (1988) & 0.24 & 11 \\
\hline
\end{tabular}

${ }^{1)} \mathrm{Rb}=\mathrm{Rb} 1+\mathrm{Rb} 2+\mathrm{Rc}+\mathrm{Rd}+\mathrm{F} 2 ;{ }^{2} \mathrm{Rg}=\mathrm{Re}+\mathrm{Rg} 1+\mathrm{F} 1$

$P$. ginseng, and results of the given test will allow assessing of similarity of cultivated cells to the cells of native plants.

\section{ACKNOWLEDGMENTS}

Authors express sincere gratitude to Doctor of Biological Sciences, professor E. N. Muratova (V. N. Sukachev Institute of Forest Russian Academy of Sciences, Siberian Branch) for learning methods, recommendations and selection of literature. Authors express gratitude to leading engineer of the biotechnology laboratory - L. D. Seletskaya for granting cell biomass of callus lines of $P$. ginseng. Research was partially supported by grant of Far East Branch of Russian Academy of Science (project no. 11-04-98515-r_vostok_a) and by grant of Russian Foundation for Fundamental Research 12-I-OBN-06, Molecular and Cell Biology grant of Russian Academy of Science Presidium.

\section{REFERENCES}

1. USSR Ministry of Agriculture. Red book of the USSR: rare and endangered species of animals and plants. Moscow: Forest Industry, 1984.

2. Takhtadjyan AL, ed. Red book of Russian Federation: plants. Moscow: Rosagropromisdat, 1988.

3. Bulgakov VP, Lauve LS, Tchernoded GK, Khodakovskaya MV, Zhuravlev YN. Chromosome variation in ginseng cells transformed with the rolC plant oncogene. Russian J Genet 2000;36:150-156.

4. Kozyrenko MM, Artyukova EV, Lauve LS, Zhuravlev YN, Reunova GD. The genetic variability of Panax ginseng callus lines. Biotechnologiya 2001;1:19-26.

5. Kunakh VA, Mozhilevskaya LP, Adonin VI, Gubar SI. Productivity and genetic structure of Panax ginseng C.A. Meyer cell populations during the in vitro cultivation. Biotechnologiya 2003;3:25-35.
6. Bayliss MV, Gould AR. Chromosomal variability in plant tissue culture. Int Rev Cytol Suppl 1980;11:113-144.

7. Grushwitsky IV. Ginseng: the aspects of biology. Leningrad: Nauka, 1961.

8. Gursenkov NN, Kolyada AS. Study of the karyotype of Panax ginseng C.A. Meyer (Araliaceae). In: Gursenkov NN, Moskaliuk TA, Chernyshev VD, eds. Biological researches of the Gornotaezhnaya station. Ussuriisk: Rossiiskaia akademiia nauk, 1996. p.101-105.

9. Lauve LS, Burundukova OL, Muzarok TI, Zhuravlev YN. Chromosome numbers of Panax ginseng (Araliaceae). Bot J 2008;93:158-161.

10. Arkhipchuk VV, Romanenko VD, Arkhipchuk MV, Kipnis LS. A cytogenetic method of determining the effect of threshold values of anthropogenic factors on plant and animal genome. Dokl Akad Nauk 1992;326:908-910.

11. Kiknadze II. Functional organization of chromosomes. Leningrad: Nauka, 1972.

12. Chelidze PV. Ultrastructure and function of a nucleolus in an interphase cell. Tbilisi: Metsniereba, 1985.

13. Gorpenchenko TY. Effect of the agrobacterium rhizogenes $\mathrm{rolC}$-gene on the processes of organogenesis and somatic embryogenesis in Panax ginseng C.A. Meyer cell culture [dissertation]. Vladivostok: Institute of Biology and Soil Science, 2006.

14. Smirnov YA. An accelerated method of studying somatic chromosomes in fruit plants. Cell Tissue Biol 1968;12:1601-1603.

15. Muratova EN. Nucleolus staining methods for karyotype analysis of conifers. Bot J 1995;80:82-86.

16. Shakhbasov VG, Shestopalova NG. Some features of the nucleolus and nucleus in cells of hybrid onion. Dokl Akad Nauk USSR 1971;196:1207-1208.

17. Sengupta J, Jha S, Sen S. Karyotype stability in long-term callus derived plants of Crepis tectorum L. Biol Plant (Praha) 1988;30:247-251.

18. Bondar LM, Tchastokolenko LV, Baranova VA. Population analysis of functional activity of the nucleolus organizer in Vicia crassa L plants. Russian J Genet 1987;23:317-324.

19. Dorofeev VY, Karnachuk RA, Pulkina SV, Komleva EV, Dubina VB, Medvedeva JV. Atragene speciosa Weinm. culture in vitro: the cytogenetic analysis and formation of triterpenoid glycosides and flavonoids. Vestnik Tomskogo Univ 2009;3:37-41. 